\title{
GAMBARAN FAKTOR RISIKO ANEMIA PADA IBU HAMIL DI WILAYAH KERJA PUSKESMAS CIPATUJAH KABUPATEN TASIKMALAYA TAHUN 2012
}

Oleh :

\author{
Santi Susanti, S.SiT, M.Kes
}

\section{A. Abstrak}

Penyebab tidak langsung kematian ibu antara lain Kurang Energi Kronis (KEK) pada kehamilan (37\%) dan anemia pada kehamilan (40\%). Kejadian anemia pada ibu hamil ini akan meningkatkan risiko terjadinya kematian ibu dibandingkan dengan ibu yang tidak anemia. Beberapa faktor risiko yang melatar belakangi status kesehatan ibu di Indonesia, dan berpengaruh terhadap kejadian kematian ibu adalah kondisi yang dikenal dengan 4 terlalu, yaitu :Terlalu dekat, jarak antara 2 persalinan $(<24$ bulan), terlalu banyak, mengalami kehamilan lebih dari 4 kali, terlalu tua, melahirkan anak pada usia diatas 35 tahun, terlalu muda, melahirkan pada usia kurang dari 20 tahun.Berdasarkan data rekam medik KIA Puskesmas Cipatujah, anemia merupakan kejadian komplikasi terbesar dari 1002 kejadian komplikasi yang ada. Tujuan penelitian yaitu untuk mengetahui Gambaran Faktor Risiko Anemia Pada Ibu Hamil di Wilayah Kerja Puskesmas Cipatujah Kabupaten Tasikmalaya tahun 2012. Manfaat penelitian yaitu dapat dijadikan masukan dalam meningkatkan asuhan kebidanan selama masa kehamilan, dan sebagai dasar dalam melakukan upaya pencegahan terjadinya anemia pada masa kehamilan dengan mempromosikan perencanaan kehamilan melalui program $K B$.

Penelitian ini merupakan jenis penelitian kuantitatif dengan metode deskriptif, populasi penelitian yaitu ibu hamil dengan anemia sebanyak 113 orang, varibel penelitian yaitu umur ibu, jarak kehamilan dan paritas. Instrumen yang digunakan adalah lembar checklist, analisis data menggunakan analisis univariat.

Hasil penelitian umur ibu yang mengalami anemia yaitu 61,1\% umur 20-35 tahun, 24,8\% umur $>35$ tahun, 14,2\% umur $<20$ tahun. Jarak kehamilan ibu yang mengalami anemia yaitu 53,1\% > 2 tahun dan 46,9\% < 2 tahun. Paritas ibu hamil dengan anemia yaitu multigravida $52,2 \%$, grandemultigravida $24,8 \%$, primigravida $23 \%$.

Kesimpulan sebagian besar umur ibu yang mengalami anemia 20-35 tahun, jarak kehamilan > 2 tahun dan paritas multigravida. Saran bagi tenaga kesehatan khususnya bidan harus melakukan upaya pencegahan dengan memfasilitasi PUS dalam merencanakan kehamilan dan memotivasi agar mengikuti program KB.

Kata Kunci : Umur ibu, jarak kehamilan, paritas 


\section{B. Latar belakang}

Dewasa ini AKI dan AKB di Indonesia masih tinggi dibandingkan dengan negara ASEAN lainnya. Menurut data Survei Demografi Kesehatan Indonesia (SDKI) 2007, AKI 228 per 100.000 kelahiran hidup, AKB 34 per 1.000 kelahiran hidup. Berdasarkan kesepakatan global (Millenium Development Goals/MDGs, 2000) pada tahun 2015 diharapkan Angka Kematian Ibu menurun sebesar tiga-perempatnya dalam kurun waktu 1990-2015 dan angka kematian bayi dan angka kematian balita menurun sebesar dua-pertiga dalam kurun waktu 19902015.

Penyebab kematian ibu dapat dibedakan menjadi penyebab langsung dan penyebab tidak langsung.Penyebab langsung kematian Ibu sebesar 90\% terjadi pada saat persalinan dan segera setelah persalinan (SKRT 2001). Penyebab langsung kematian ibu adalah perdarahan (28\%), eklampsia (24\%) dan infeksi (11\%). Sedangkan berdasarkan laporan rutin PWS tahun 2007, penyebab langsung kematian ibu adalah perdarahan (39\%), eklapmsia (20\%), infeksi $(7 \%)$ dan lain-lain (33\%).Penyebab tidak langsung kematian ibu antara lain Kurang Energi Kronis (KEK) pada kehamilan (37\%) dan anemia pada kehamilan (40\%). Kejadian anemia pada ibu hamil ini akan meningkatkan risiko terjadinya kematian ibu dibandingkan dengan ibu yang tidak anemia.

Anemia pada ibu hamil merupakan masalah kesehatan terkait dengan insidennya yang tinggi dan komplikasi yang dapat timbul baik pada ibu maupun pada janin. Di dunia $34 \%$ ibu hamil dengan anemia dimana $75 \%$ berada di negara sedang berkembang (Syafa, 2010). Berdasarkan hasil Survei Kesehatan Rumah Tangga (SKRT) pada tahun 2010 menunjukkan $57.1 \%$ remaja putri, $39.5 \%$ wanita usia subur dan $50.9 \%$ ibu hamil menderita anemia (Dinkes propinsi Jawa Barat, 2012). Sedangkan berdasarkan hasil Survei Kesehatan Rumah Tangga (SKRT) pada tahun 2011 menunjukkan $26,5 \%$ remaja putri; $40 \%$ wanita usia subur dan $47 \%$ anak usia tahun menderita anemia (Dinkes Jawa Barat, 2012).

Dampak anemia pada ibu maupun janin yang mengalami anemia adalah premature, IUFD (Intra Uterine Fetal Death), keguguran, stillbirth (kematian janin waktu lahir), kecacatan, cadangan besi kurang, syok, perdarahan postpartum karena atonia uteri, partus lama karena inersia uteri, infeksi baik intrapartum maupun postpartum.

Beberapa faktor risiko yang melatar belakangi status kesehatan ibu di Indonesia, dan berpengaruh terhadap kejadian kematian ibu adalah kondisi yang dikenal dengan 4 terlalu, yaitu :Terlalu dekat, jarak antara 2 persalinan ( $<24$ bulan), terlalu banyak, mengalami kehamilan lebih dari 4 kali, terlalu tua, melahirkan anak pada usia diatas 35 tahun, terlalu muda, melahirkan pada usia kurang dari 20 tahun. Menurut Arisman $(2004 ; 150)$ bahwa jarak kurang dari 2 tahun merupakan faktor terjadinya anemia yang berhubungan dengan jarak kehamilan. Jarak yang terlalu dekat yaitu $<2$ tahun yang disebabkan karena terlalu cepat ibu hamil hamil kembali sehingga kondisi ibu belum pulih. Jarak lebih dari 2 tahun merupakan jarak paling aman ditinjau dari sudut kematian maternal. Jarak kurang dari 2 tahun mempunyai angka kematian maternal lebih tinggi. Lebih dekat jarak, lebih tinggi kematian maternal. Resiko pada jarak lebih dari 2 tahun dapat ditangani dengan asuhan obstetrik yang baik, sedangkan resiko pada jarak kurang dari 2 tahun dapat dikurangi atau dicegah dengan keluarga berencana. Sebagian kehamilan pada jarak yang terlalu dekat adalah tidak direncanakan. (Saifuddin,2007;23). Menurut penelitian 
Amiruddin, mengenai hubungan jarak kehamilan dengan kejadian anemia di wilayah kerja Puskesmas Bantimurung Kabupaten Maros tahun 2004 dengan jumlah sampel 128 ibu hamil bahwa hubungan jarak kehamilan dengan kejadian anemia dan responden yang paling banyak menderita anemia adalah pada jarak kurang dari 2 tahun dengan jumlah $61(62.5 \%)$ orang dan terendah pada responden yang jarak lebih dari 2 tahun dengan jumlah $10(54.5 \%)$ orang. Berdasarkan data rekam medik Puskesmas Cipatujah terdapat beberapa masalah yang terkait dengan Kesehatan Ibu dan Anak (KIA). Pada tahun 2011 dari jumlah ibu hamil 1989 orang, terdapat $848 \mathrm{ibu}$ hamil yang menderita

\section{Metode}

Jenis penelitian termasuk penelitian kuantitatif dengan menggunakan metode deskriptif untuk menggambarakan faktor risiko anemia pada ibu hamil diantaranya umur ibu, jarak kehamilan dan paritas pada ibu yang mengalami anemia di Wilayah kerja Puskesmas Cipatujah Kabupaten Tasikmalaya Tahun 2012.

Populasi dalam penelitian ini adalah seluruh ibu hamil yang mengalami anemia di Wilayah Kerja Puskesmas Cipatujah Kabupaten Tasikmalaya tahun 2011 sebanyak 113 orang. Tehnik pengambilan sampel dilakukan secara total sampling.

Instrument yang digunakan dalam penelitian ini adalah dengan menggunakan lembar checklist. Tehnik pengumpulan data yang digunakan dalam penelitian ini adalah dengan data sekunder, yaitu data yang diperoleh dari bagian rekam medik Puskesmas Cipatujah Kabupeten Tasikmalaya tahun 2011. Data responden yang ada di rekam medic dimasukkan ke lembar ceklist sesuai dengan kondisi responden. anemia. Jumlah kejadian abortus 321 kasus.

Berdasarkan data rekam medik KIA Puskesmas Cipatujah, anemia merupakan kejadian komplikasi terbesar dari 1002 kejadian komplikasi yang ada. Berdasarkan uraian di atas peneliti tertarik melakukan penelitian yang berjudul "Gambaran Faktor Risiko Anemia Pada Ibu Hamil di Wilayah Kerja Puskesmas Cipatujah Kabupaten Tasikmalaya tahun 2012"?

Tujuan penelitian adalah untuk mengetahui Gambaran Faktor Risiko Anemia Pada Ibu Hamil di Wilayah Kerja Puskesmas Cipatujah Kabupaten Tasikmalaya tahun 2012.

Pengolahan data dilakukan dengan perangkat computer yang sebelumnya dilakukan langkah-langkah sebagai berikut (Arikunto,2002)

1. Editing

Peneliti menyeleksi data yang diperoleh dari responden untuk mengurangi kesalahan atau kekurangan yang ada di dalamnya. Peneliti melihat apakah jawaban responden pada kuesioner yang telah terkumpul diperiksa ulang untuk mengetahui isi datanya.

2. Coding

Peneliti dalam tahap ini mengklasifikasikan jawaban responden ke dalam kategori-kategori dengan cara memberi kode pada data yang sudah diolah untuk memudahkan dalam menganalisis data.

\section{Tabulating}

Tabulasi data yang dilakukan oleh peneliti membuat tabel jawaban-jawaban yang sudah diberi kode kategori jawaban dimasukkan kedalam tabel. Melakukan pengolahan data berdasarkan hasil kuesioner setelah melakukan edit data dan kode data. 


\section{Processing}

Langkah selanjutnya peneliti memproses data dan dianalisis, processing data dilakukan dengan cara memasukan data dari kuesioner ke paket program computer.

5. Cleaning

Peneliti pada tahap ini melakukan pengecekan kembali data yang sudah diproses apakah ada kesalahan atau tidak.

\section{Analisis Data}

Analisis yang digunakan dalam penelitian ini adalah analisis univariat menggunakan rumus :

$\mathrm{P}=\mathrm{X} / \mathrm{N} \times 100 \%$

Keterangan :

$\mathrm{P}=$ Prosentase

$\mathrm{X}=$ Jumlah jawaban yang benar

$\mathrm{N}=$ Jumlah seluruh pertanyaan

\section{Hasil penelitian}

\section{Umur}

Tabel 5.1 Distribusi Frekeunsi Umur ibu hamil dengan anemia di Puskesmas Cipatujah Kabupaten Tasikmalaya tahun 2012.

\begin{tabular}{|l|c|c|}
\hline \multicolumn{1}{|c|}{ Kategori } & Jumlah & $\begin{array}{c}\text { Persentase } \\
(\boldsymbol{\%})\end{array}$ \\
\hline$<20$ tahun & 16 & 14,2 \\
\hline $20-35$ tahun & 69 & 61 \\
\hline$>35$ tahun & 28 & 24,8 \\
\hline Jumlah & 113 & 100 \\
\hline
\end{tabular}

Berdasarkan tabel diatas dapat dilihat bahwa ibu yang mengalami anemia sebagian besar memiliki umur pada $(61 \%)$, selanjutnya 28 orang $(24,8 \%)$ berusia $>35$ tahun dan 16 orang $(14,2 \%)$ rentang 20-35 tahun yaitu 69 orang berusia $<20$ tahun.

2. Jarak Kehamilan

Tabel 5.2 Distribusi Frekeunsi Jarak kehamilan ibu dengan anemia di Puskesmas Cipatujah Kabupaten Tasikmalaya tahun 2012.

\begin{tabular}{|l|c|c|}
\hline Kategori & Jumlah & Persentase (\%) \\
\hline$<2$ tahun & 53 & 46,9 \\
\hline$>2$ tahun & 60 & 53,1 \\
\hline Jumlah & 113 & 100 \\
\hline
\end{tabular}

Berdasarkan tabel diatas dapat dilihat bahwa ibu yang mengalami anemia mempunyai jarak kehamilan $>2$ tahun

3. Paritas

Tabel 5.3 Distribusi Frekeunsi Paritas ibu dengan anemia di Puskesmas Cipatujah Kabupaten Tasikmalaya tahun 2012.

\begin{tabular}{|l|c|c|}
\hline \multicolumn{1}{|c|}{ Kategori } & Jumlah & $\begin{array}{c}\text { Persentase } \\
(\mathbf{\%})\end{array}$ \\
\hline Primigravida & 26 & 23 \\
\hline Multigravida & 59 & 52,2 \\
\hline Grande multigravida & 28 & 24,8 \\
\hline Jumlah & 113 & 100 \\
\hline
\end{tabular}

yaitu 60 orang $(53,1 \%)$, dan yang mempunyai jarak kehamilan $<2$ tahun sebanyak 53 orang $(46,9 \%)$. 
Berdasarkan tabel diatas dapat diketahui bahwa sebagian besar ibu yang mengalami anemia mempunyai paritas multigravida yaitu sebanyak 59 orang

\section{E. Pembahasan}

\section{Umur Ibu}

Hasil penelitian menunjukan bahwa distribusi responden berdasarkan umur ibu pada ibu hamil dengan anemia di Wilayah Kerja Puskesmas Cipatujah Kabupaten Tasikmalaya Tahun 2012, yaitu ibu yang berada pada rentang usia 20-35 tahun sebanyak 69 orang $(61 \%)$, > 35 tahun sebanyak 28 orang $(24,8 \%)$, < 20tahun sebanyak 16 orang (14,2\%).

Apabila melihat data diatas usia dominan pada ibu yang mengalami anemia ada pada usia 20-35 tahun yaitu sebesar $61 \%$. Meskipun usia tersebut bukan merupakan faktor risiko kehamilan, namun di Indonesia wanita di atas usia 30 tahun banyak yang memilih jarak pendek untuk melahirkan anak sebelum mereka berumur 35 tahun ke atas (Yolan, 2007). Sehingga meskipun dari segi usia masih tergolong usia reproduksi sehat namun, jarak kehamilan yang pendek menyebabkan ibu mengalami anemia.

Apabila melihat data hasil penelitian ibu hamil dengan anemia yang memiliki umur berisiko juga cukup banyak yaitu 39\%. Ibu hamil pada usia terlalu muda $(<20$ tahun) tidak atau belum siap untuk memperhatikan lingkungan yang diperlukan untuk pertumbuhan janin. Disamping itu akan terjadi kompetisi makanan antar janin dan ibunya sendiri yang masih dalam pertumbuhan dan adanya pertumbuhan hormonal yang terjadi selama kehamilan.Sedangkan ibu hamil diatas 30 tahun lebih cenderung mengalami anemia, hal ini disebabkan karena pengaruh turunnya hemoglobin.

Kesimpulan yang dapat ditarik adalah usia kurang dari 20 tahun dan lebih dari 35 tahun merupakan risiko terjadinya anemia dalam kehamilan,
$(52,2 \%)$, grande multigravida sebanyak 28 orang $(24,8 \%)$ dan primigravida sebanyak 26 orang $(23 \%)$.

namun ibu hamil dengan usia 20-35 tahun juga bisa mengalami anemia dalam kehamilan karena ada faktor lain yang menyebabkan ibu kekurangan nutrisi (zat besi).

\section{Jarak Kehamilan}

Hasil penelitian menunjukan bahwa distribusi responden berdasarkan jarak kehamilan pada ibu hamil dengan anemia di Wilayah kerja Puskesmas Cipatujah Kabupaten Tasikmalaya tahun 2012, ibu hamil dengan jarak kehamilan lebih dari 2 tahun sebanyak 60 orang $(53,1 \%)$ dan ibu hamil dengan jarak kehamilan kurang dari 2 tahun sebanyak 53 orang $(46,9 \%)$.

Jarak kehamilan adalah jarak antara kehamilan sebelumnya dengan kehamilan berikutnya. Jarak kehamilan yang baik minimal 2 tahun. Jarak kehamilan kurang dari 2 tahun berpengaruh terhadap kejadian anemia (Ammarudin, 2004).

Secara medis, rahim sebenarnya sudah siap untuk hamil kembali tiga bulan setelah melahirkan. Namun berdasarkan catatan statistik penelitian bahwa jarak kelahiran yang aman antara anak satu dengan lainnya adalah 27 sampai 32 bulan. Pada jarak ini si ibu akan memiliki bayi yang sehat serta selamat saat melewati proses kehamilan (Agudelo, 2007).

Wanita yang melahirkan dengan jarak yang sangat berdekatan $(<2$ tahun) akan mengalami resiko antara lain (Yolan, 2007) : resiko perdarahan trimester III, plasenta previa, anemia, ketuban pecah dini, endometriosis masa nifas. kematian saat melahirkan, kehamilan dengan jarak yang terlalu jauh juga dapat menimbulkan resiko tinggi antara lain persalinan lama.

Menentukan jarak kehamilan tidak semua pasangan usia subur mengetahui 
secara jelas manfaatnya buat kehidupan jangka panjang yang lebih baik. Maka yang paling penting dalam hal ini adalah meningkatkan peran suami istri dalam memahami betul manfaat menentukan jarak kehamilan. Dimana, terdapat keadaan bahwa jarak kehamilan yang diinginkan sebagian besar wanita di negara berkembang tersebut tidak selalu terpenuhi. Perencanaan berkeluarga yang optimal melalui perencanaan kehamilan yang aman, sehat dan diinginkan merupakan salah satu faktor penting dalam upaya menurunkan angka kematian maternal. Menjaga jarak kehamilan tak hanya menyelamatkan ibu dan bayi dari sisi kesehatan, namun juga memperbaiki kualitas hubungan psikologis keluarga (Sugiri, 2007). Salah satu perencanaan kehamilan antara lain dengan mengikuti program Keluarga Berencana (KB). KB memberi kepada pasangan pilihan tentang kapan sebaiknya mempunyai anak, berapa jumlahnya, jarak antar anak yang satu dengan yang lain, dan kapan sebaiknya berhenti mempunyai anak (Yolan, 2007).

Jarak kehamilan atau kelahiran yang berdekatan juga dapat memicu pengabaian pada anak pertama secara fisik maupun psikis, yang dapat menimbulkan rasa cemburu akibat ketidaksiapan berbagi kasih sayang dari orang tuanya (Yolan, 2007). Banyak kakak-beradik dengan jarak kehamilan atau kelahiran terlalu pendek menimbulkan sikap iri atau cemburu. Seperti kakak tidak gembira atas kehadiran si kecil, justru sering menganggapnya musuh karena merampas jatahkasih sayang orang tuanya (Diana, 2007).

Kesimpulan yang dapat ditarik dari penjelasan diatas adalah meskipun sebagian besar ibu hamil yang mengalami anemia memiliki jarak kehamilan lebuh dari 2 tahun, namun anemia dalam kehamilan masih bisa terjadi karena penyebab lain misalnya pemenuhan nutrisi yang kurang karena ibu hamil masih memiliki balita yang sama memerlukan asupan nutrisi yang baik bagi pertumbuhannya.

\section{Paritas}

Hasil penelitian menunjukan bahwa distribusi responden berdasarkan paritas pada ibu hamil dengan anemia di Wilayah kerja Puskesmas Cipatujah Kabupaten Tasikmalaya tahun 2012, ibu hamil dengan paritas multigravida sebanyak 59 orang (52.2\%), grande multigravida 28 orang $(24,8 \%)$ dan primigravida 26 orang $(23 \%)$.

Melihat data diatas sebagian besar $52,2 \%$ ibu hamil dengan anemia memiliki paritas multigravida (2-4 kali hamil). Dan terdapat $24,8 \%$ memiliki paritas grandemultigravida. Paritas yang berisiko mengalami anemia yaitu $>4$ atau grandemultigravida. Akan tetapi pendapat Arisman Paritas $>3$ merupakan faktor terjadinya anemia. Hal ini disebabkan karena terlalu sering hamil dapat menguras cadangan zat gizi tubuh ibu. Meskipun paritas multigravida bukan merupakan faktor risiko terjadinya anemia pada ibu hamil, namun tak jarang jarak kehamilan yang cukup dekat menjadi hal yang menyertai kehamilan ibu dengan paritas multigravida, sehingga anemia tetap dapat terjadi. 


\section{F. Simpulan dan saran}

Kesimpulan yang di dapat bahwa hubungan antara jarak kehamilan dengan anemia pada Ibu Hamil di Puskesmas Cipatujah Kabupaten Tasikmalaya tahun 2012 diuraikan sebagai berikut

1. Sebagian besar ibu hamil dengan anemia di Wilayah Kerja Puskesmas Cipatujah Kabupaten Tasikmalaya Tahun 2012 ada pada umur 20-35 tahun.

2. Sebagian besar jarak kehamilan ibu hamil dengananemia di Wilayah Kerja Puskesmas Cipatujah Kabupaten Tasikmalaya Tahun $2012>2$ tahun.

3. Sebagian besar paritas ibu hamil dengan anemia di Wilayah Kerja Puskesmas Cipatujah Kabupaten Tasikmalaya Tahun 2012 memiliki paritas multigravida.

\section{Saran}

1. Tenaga Kesehatan

Sebaiknya tenaga kesehatan khususnya bidan melakukan upaya promotif untuk mencegah terjadinya anemia pada masa kehamilan dengan membantu pasangan usia subur melakukan perencanaan kehamilan dan memotivasi mereka untuk mengikuti program KB.

2. Bagi Ibu

Ibu hamil dapat segera merencanakan kehamilan selanjutnya dengan mengikuti program KB.

\section{G. Referensi}

Atikah, S. (2011). Anemia dan anemia kehamilan Edisi Revisi 6. Rineka Cipta. Jakarta, Hal 55-77.

Atikah, S. (2009) Cara mudah mengatasi anemia Edisi 1. Rineka Cipta. Jakarta, Hal 22-55.

Ratna, D. (2012), Asuhan Kebidana, Edisi Revisi 6, Penerbit Nuh Medika, Jakarta : Rineka Cipta, Hal 45-61..

Ammarudin. 2004. Hubungan jarak kehamilan dengan kejadian anemia pada ibu hamil. Di unduh tanggal 10 April 2012 Tersedia dari

http://ammirudin.wordpress.com/ 2008/01/24/anemia-pada-ibu hamil/trackback

Dinas Kesehatan. 2011. Provinsi Jabar Profil Kesehatan 2011. Di unduh tanggal 10 April 2012. Tersedia dari:

http://www.dinkesjatengprov.go.i d/dokumen/profil/2011/profil2011

Dinkes, Kabupaten Tasikmalaya. 2012. Profil Kesehatan Kabupaten Pekalongan. Tasikmalayan, Dinkes Tasikmalaya.

Khoiri, H. 2010. Tanya Jawab Kesehatan Harian Untuk Ibu ibu. Jogjakarta: Tunas Publishing. Istiarti. 2000. Menanti Buah Hati. Yogyakarta: Media Persido: Media Persido.

Manuaba, I. B. G. Ilmu Kebidanan Penyakit kandungan dan Keluarga Berencana. Jakarta : EGC; 2008

Manuaba, I. B. G. Kapita Selekta Penatalaksanaan Rutin Obstetri Ginekologi dan Keluarga Berencana. Jakarta. EGC; 2005

Manuaba, I. B. G. (2002). Konsep Obstetric\& Ginekologi Sosial Indonesia.Jakarta. EGC

Manuaba, I. B. G. 2003. Buku Saku Ilmu Kandungan. Jakarta: EGC.

Mochtar, R. (2008). Synopsis Obstetri Fisiologi Patofisiologi. Jakarta : EGC.

Musbikin, I. 2007. Persiapan Menghadapi Persalinan. Yogyakarta : Mitra Pustaka

Notoatmodjo, S. (2010). Ilmu Kesehatan Masyarakat. Jakarta : Rineka Cipta.

Notoatmodjo, S. (2010). Metodologi Penelitian Kesehatan. Jakarta: Rineka Cipta 